\title{
Organization of the Mouse and Human Carbonic Anhydrase II Genes ${ }^{a}$
}

\author{
PATRICK J. VENTA, JEFFRY C. MONTGOMERY, \\ KARIN WIEBAUER, ${ }^{b}$ DAVID HEWETT-EMMETT, \\ and RICHARD E. TASHIAN \\ Department of Human Genetics \\ University of Michigan Medical School \\ Ann Arbor, Michigan 48109
}

\section{INTRODUCTION}

The carbonic anhydrase (CA) multigene family is beginning to appear more complex than was considered possible during the earlier days of work on the different isozymes. The two classic erythrocyte isozymes found in amniotes, CA I and CA II, have been studied in considerable detail in terms of their kinetics, structures, and evolution..$^{1-7}$ Within the last few years, at least one other isozyme (CA III), which is coded by a separate locus, has been shown to exist. ${ }^{7}$ In addition, membrane-bound carbonic anhydrases in brain, ${ }^{8}$ lung,, 910 and kidney, ${ }^{11,12}$ and a soluble CA in mitochondria ${ }^{13,14}$ have been characterized and may be the products of loci distinct from the genes coding for the CA I, CA II, and CA III isozymes. However, assignment of these CA isozymes to their respective loci has been a difficult task, complicated by the possibility that two or more genes can code for an identical protein product, as has been shown for human $\alpha$-globin ${ }^{15}$ and human placental lactogen, ${ }^{16}$ or that one gene can code for different protein products, as in the case of the human calcitonin gene. ${ }^{17,18}$ Clearly, determination of the number of expressed (as well as unexpressed) genes will require work at the DNA and RNA level.

The linkage relationships among the members of the CA multigene family are only partially known. In mice, the loci for CA I and CA II are tightly linked near the centromere of chromosome $3 ;^{19}$ in humans, the CA II gene is present on chromosome $8{ }^{20}$ The location of the human CA I gene is not yet known. However, additional linkage data from work on pigtail macaques ${ }^{21}$ and guinea pigs ${ }^{22}$ support the notion that CA I and CA II are linked in all mammals. No data are presently available concerning the location of the CA III gene in any species. If all the CA isozyme genes are indeed linked, they may constitute a complex regulatory system, the study of which could lead to insights into various levels of eukaryotic gene regulation.

Deficiencies of erythrocyte CA I and CA II have been found in humans. An inherited deficiency of CA I has been described in three members of a Greek family who, despite a virtually complete absence of the enzyme in erythrocytes,

- This work was supported by NIH Grants GM24681 (R.E.T.) and GM24872 (M. H. Meisler), by an Arthur F. Thurnau fellowship (K.W.), and by NIH predoctoral grant 5 T32 GM07315-09 (J.C.M.).

${ }^{b}$ Present address: Department of Toxicology, University of Hamburg Medical School, D-2000 Hamburg 13, FRG. 
show no clinical manifestations. ${ }^{23}$ On the other hand, humans with deficiency of red cell CA II suffer from a syndrome of osteopetrosis with renal tubular acidosis and cerebral calcification. ${ }^{24.25}$ While there are several genetically distinct forms of osteopetrosis in humans and other mammals, ${ }^{26}$ the form caused by CA II deficiency has been found only in humans. ${ }^{25}$ The molecular basis of the CA I and CA II deficiencies is unknown. As with the well-characterized globin system, ${ }^{27}$ a fuller understanding of the genetic lesions that cause these deficiencies will require study of the genes at the DNA level.

As a first step to answering the questions raised above, we have set out to isolate the genes for the carbonic anhydrase isozymes. Here, we describe the isolation of clones containing mouse and human CA II sequences and the initial characterization of these clones.

\section{MATERIALS AND METHODS}

\section{Mouse CA II cDNA Probe}

The mouse CA II clone, pMCAII, (kindly provided by Dr. P. J. Curtis) was isolated from a cDNA library derived from splenic mRNA of an anemic Balb/c mouse. ${ }^{28,46}$ The nearly full-length $1.5-\mathrm{kb}$ insert was purified from the vector as previously described by centrifugation through a sucrose gradient and this insert was then nick-translated to $1-2 \times 10^{8} \mathrm{cpm} / \mu \mathrm{g} .{ }^{20}$ Probes representing the $5^{\prime}$, middle, and $3^{\prime}$ regions of the cDNA were derived from the Pst I fragments of pMCAII (see FIG. 1).

\section{Cosmid and Lambda Libraries}

The mouse lambda and cosmid libraries were constructed as described. ${ }^{55}$ Briefly, high molecular weight DNA was prepared from the livers of YBR mice, partially digested with $\mathrm{Mbo} \mathrm{I}$, size-selected on a sucrose gradient, ${ }^{56}$ and ligated into the Bam HI site of either the lambda vector Charon $30^{30}$ or $\mathrm{pJB8}{ }^{31,57}$ (a cosmid vector partially derived from pBR322 and kindly provided by $R$. W. Padgett). The pJB8 vector was prepared for ligation as described. ${ }^{31}$ Recombinant molecules were packaged in vitro into lambda phage particles ${ }^{58}$ and used to infect $E$. coli $K 803^{61}$ for the lambda libraries and $E$. coli $490 \mathrm{~A}^{62}$ for the cosmid libraries. The phages were plated at 50,000 plaques per $150-\mathrm{mm}$ plate and the cosmids at 10,000 colonies per $150-\mathrm{mm}$ plate. Each library was large enough to ensure that at least

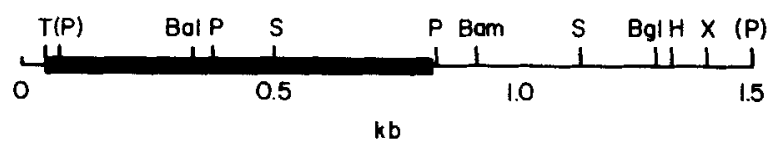

FIGURE 1. Restriction map of mouse CA II cDNA. This map was generated from two overlapping cDNA clones, one of which was pMCAII, which includes the entire sequence except for the 5 ' untranslated region and the first eight amino acids of the coding region. Heavy line $=$ translated region; thin line $=$ untranslated regions. $\mathrm{S}=$ St $u \mathrm{I}, \mathrm{P}=$ Pst $\mathrm{I}, \mathrm{H}=$ Hind III, X $=X b a I$, Bal $=B a l \mathrm{I}, \mathrm{Bam}=B a m \mathrm{HI}, \mathrm{T}=T$ th $111 \mathrm{I}$, and $\mathrm{Bgl}=B g l \mathrm{II} .(\mathrm{P})=$ the artificial Pst I sites generated during the cloning process in pMCAII. 
one genomic equivalent was plated. ${ }^{59}$ The DNA from colonies or plaques were fixed onto nitrocellulose filters and hybridized as described below.

The human genomic lambda library ${ }^{32}$ was kindly provided by Dr. T. Maniatis.

\section{Hybridizations and Southern Blots}

After digestion with restriction enzymes and electrophoresis of $0.8 \%$ agarose gels, genomic DNA was transferred to nitrocellulose ${ }^{33}$ and hybridized with the appropriate probe in $5 \mathrm{XSSC}(1 \mathrm{XSSC}=15 \mathrm{~m} M$ sodium citrate, $0.15 M$ sodium chloride), $5 \mathrm{X}$ Denhardt's solution ( $1 \mathrm{X}=0.02 \%$ each of Ficoll, polyvinylpyrrolidone, and bovine serum albumin), ${ }^{34} 10 \%$ dextran sulfate, $200 \mu \mathrm{g} / \mathrm{ml}$ denatured salmon testes DNA, and 35-50\% formamide depending on the experiment. All hybridizations were performed at $42^{\circ} \mathrm{C}$ for $12-48 \mathrm{hr}$. Multiple washes (4-6) with $2 \mathrm{XSSC}, 0.1 \% \mathrm{SDS}$ were done at $50^{\circ} \mathrm{C}$ sometimes followed by more stringent washes with $0.1 \mathrm{XSSC}, 0.1 \%$ SDS at $50^{\circ} \mathrm{C}$. Hybridizations for screening of the mouse cosmid and lambda libraries were modified from previously existing protocols. ${ }^{35,36,60}$ Hybridizations for the human lambda library were performed at reduced stringency to obtain better signals with the mouse probe. ${ }^{20}$

\section{Isolation of Cloned DNAs}

Cosmids and plasmids were isolated after amplification in L-broth ${ }^{29}$ using the boiling method ${ }^{37}$ followed by banding in $\mathrm{CsCl}$-ethidium bromide gradients. Residual bacterial RNA was removed by chromatography on Sephacryl S-300. ${ }^{38}$ Minipreparations were also performed using the boiling method. Lambda phase DNAs were isolated by standard techniques ${ }^{29}$ after plaque purification. Eco RI fragments were subcloned using the plasmid vector pBR325 $5^{39,40}$ and $E$. coli $\mathrm{DH} 1^{41}$ as the host.

\section{Restriction Mapping}

Maps were constructed by performing single and double digestions for enzymes that cut only a few times and by partial digestion mapping for enzymes that cut many times. ${ }^{42}$ Partial digestion mapping was carried out by first linearizing the cosmids by cutting with $M l u \mathrm{I}$, which has only one recognition site in pJB8 and none in any of the genomic DNA inserts. Following partial digestion with an appropriate second restriction enzyme (e.g., $E_{c o}$ RI), the DNA was run on a $0.8 \%$ agarose gel and blotted onto nitrocellulose. After hybridization with a probe that binds with only vector sequences to the left or right side of the cloning site (i.e., the $E$ co RI-Bam HI or Eco RI-Pst I fragment of pBR322, respectively), the blot was washed and autoradiographed. The banding pattern thus displayed the direct order and spacing of the restriction sites for the second enzyme from either end of the insert depending on which probe was used.

\section{DNA Sequencing}

DNA fragments were labeled at the $5^{\prime}$ ends using polynucleotide kinase, digested with a second enzyme, and separated by polyacrylamide gel electrophore- 
sis. Bands were located by alignment with Polaroid Type 52 or 57 film that had been exposed to the gel for several minutes, cut from the gel, and eluted ${ }^{43}$ Fragments were subjected to the chemical degradation methods of Maxam and Gilbert, ${ }^{43}$ electrophoresed in thin $8 M$ urea-containing polyacrylamide gels, and exposed to Kodak AR-5 film with Dupont Cronex Lightning Plus intensifying screens. ${ }^{44}$

\section{RESULTS}

\section{Southern Blot Analysis of the Mouse CA II Genomic Sequences}

A summary of the hybridizing bands seen on genomic blots of C57BL/6 DNA using pMCAII as the labeled probe is given in TABLE 1 . A representative autoradiogram is shown in FigURE 2. A comparison of C57BL/6 DNA with YBR DNA showed no discernible differences when using Bam HI, Bgl I, Sph I, or Hind III (data not shown). An apparent difference occurs with BglII as shown by a $4.4 \mathrm{~kb}$ fragment in C57BL/6 DNA (TABLE 1) instead of the $5.1 \mathrm{~kb}$ fragment found in cosmid clone A6 (TABLE 2).

Using the three $P$ st I fragments from pMCAII as probes, it was found that the 3.5-kb Eco RI and the 6-kb Bam HI bands contain the 3' end of the gene, and the 2.7-kb Eco RI and the 15-kb Bam HI bands contain the 5' portion of the gene.

A restriction map of the CA II gene region could not be constructed using these results plus data produced by digesting with two restriction enzymes, a method that has proven successful with some small genes such as rabbit $\beta$-globin. ${ }^{45}$ It therefore seemed likely that the CA II gene was comparatively large, and that internal (i.e., intronic) nonhybridizing fragments were not detected, making map construction by this method unfeasible.

\section{Mouse CA II Genomic Clones}

Genomic sequences hybridizing to the labeled pMCAII probe were isolated from both cosmid and lambda genomic libraries. Four cosmid clones, A5, A6, 54, and 103, and several lambda clones were found. All of the cosmid and four of the lambda clones, 8.1, 8.2, 9.1, and 15.1, were studied in some detail.

\section{Cosmid Clone A6}

A complete mouse CA II gene is contained within this cosmid clone as shown by the correspondence of the cosmid A6 hybridizing bands with those seen on

TABLE 1. Restriction Fragment Sizes of Mouse CA II Hybridizing Bands from Genomic Blots ${ }^{a}$

\begin{tabular}{cccc}
\hline Eco $\mathrm{RI}$ & Bam HI & Hind III & Bgl II \\
\hline 7.2 & 15 & 12 & 4.4 \\
3.5 & 6.2 & 4.2 & 3.1 \\
2.7 & & 2.2 & 2.9 \\
& & 0.6 & 2.8 \\
& & & 1.4 \\
& & & 1.2 \\
\hline
\end{tabular}

${ }^{a}$ Fragment sizes are given in kilobase pairs. 
FIGURE 2. A representative autoradiogram used in genomic blot analysis of mouse CA II gene sequences. The lanes are: (1) $\mathrm{Bgl} \mathrm{II}$; (2) Hind III; (3) Bam HI; (4) Eco $\mathrm{RI}$; and (5) $X b a$ I. Bands smaller than $1.4 \mathrm{~kb}$ were lost off the end of this particular gel. The DNA in this gel is from mouse stain C57B1/6. This gel was hybridized under reduced stringency ( $40 \%$ formamide) and shows bands that are not present under more stringent conditions in addition to those listed in TABLE 1. Molecular weights on the left side of the figure are in kilobase pairs.

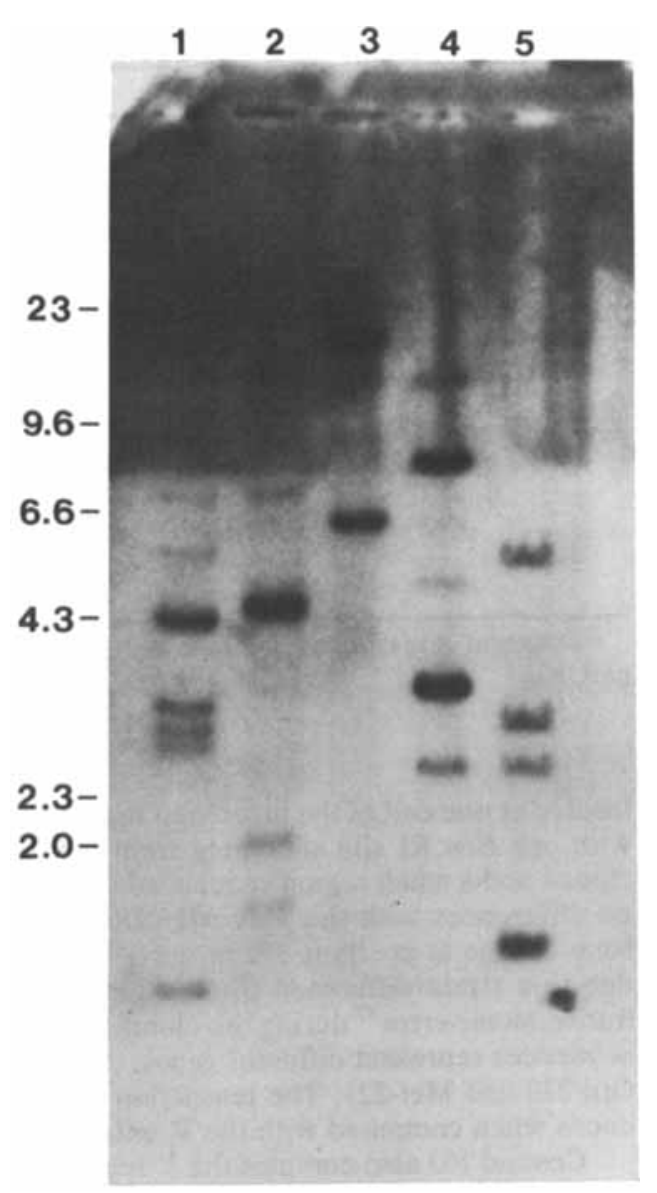

genomic blots (TABLES 1 and 2). A restriction map of this clone is shown in FIGURE 3. This map shows no inconsistencies with the data derived from the genomic blots. The 38-kb-long genomic fragment contains, in addition to the 16kb-long gene, $12-\mathrm{kb}$ of $5^{\prime}$ flanking region and $10-\mathrm{kb}$ of $3^{\prime}$ flanking region. One intervening sequence is over $5-\mathrm{kb}$ in length. From the presence of $6 \mathrm{Bgl}$ II bands hybridizing to pMCAII, and the fact that pMCAII has only one $B g$ l II site, it can be deduced that there are at least 5 exons.

\section{Cosmids Clones $A 5,54$, and 103}

Cosmid A5 contains the 3' end of a CA II gene as shown by the 3.5-kb Eco RI band that hybridizes with pMCAII. No other hybridizing regions are present. The Eco RI restriction pattern differs from that of the other cosmids (TABLE 2), although a few of the bands are of a similar size to those of the other cosmids.

Cosmid 54 also contains the $3^{\prime}$ end of a CA II gene. The Eco RI restriction fragment sizes of the clone are given in TABLE 2. The $2.5-\mathrm{kb}$ Eco RI fragment is 
TABLE 2. Restriction Fragment Sizes of Mouse Cosmid Clones ${ }^{a}$

\begin{tabular}{|c|c|c|c|c|c|c|}
\hline \multicolumn{4}{|c|}{ A6 } & \multirow{2}{*}{$\frac{54}{E c o \text { RI }}$} & \multirow{2}{*}{$\frac{103}{E c o \mathrm{RI}}$} & \multirow{2}{*}{$\frac{\text { A5 }}{E c o \text { RI }}$} \\
\hline Eco RI & Bam HI & Hind III & Bgl II & & & \\
\hline $\begin{array}{l}7.2^{*} \\
7.0 \\
5.4 \\
5.0 \\
4.2 \\
3.5^{*} \\
3.4 \\
2.8 \\
2.7^{*} \\
2.0 \\
1.0\end{array}$ & $\begin{array}{l}25 \\
15.0^{*} \\
6.2^{*} \\
0.7\end{array}$ & $\begin{array}{l}12.0^{*} \\
9.1 \\
8.3 \\
6.0 \\
4.2^{*} \\
2.2^{*} \\
0.9 \\
0.9 \\
0.9^{*} \\
0.6\end{array}$ & $\begin{array}{l}18 \\
5.1^{*} \\
3.1^{*} \\
2.9^{*} \\
2.8^{*} \\
2.0 \\
1.8 \\
1.6 \\
1.5 \\
1.4^{*} \\
1.3^{*} \\
1.2^{*}\end{array}$ & $\begin{array}{l}8.9 \\
7.2 \\
5.4 \\
4.2 \\
3.8 \\
2.5^{*} \\
1.8 \\
1.8 \\
1.5 \\
1.2 \\
1.0 \\
0.9 \\
0.8 \\
0.4\end{array}$ & $\begin{array}{l}8.7 \\
5.4 \\
5.1 \\
4.4 \\
4.0 \\
3.3 \\
2.0^{*} \\
1.8^{*} \\
1.4 \\
1.0 \\
0.9 \\
0.4 \\
0.2 \\
0.1\end{array}$ & $\begin{array}{l}8.3 \\
6.9 \\
5.4 \\
4.4 \\
4.2 \\
3.5^{*} \\
2.8 \\
2.7 \\
2.1 \\
1.8 \\
1.5 \\
1.4 \\
0.4 \\
0.3\end{array}$ \\
\hline
\end{tabular}

${ }^{a}$ Fragment sizes are in kilobase pairs and an asterisk indicates hybridization with pMCAII.

located at one end of the insert and represents a truncated 3.5-kb Eco RI fragment with one Eco RI site stemming from the vector. The 2.5 -kb fragment was subcloned and a small region sequenced (FIG. 4). This preliminary sequence showed no differences with the pMCAII cDNA sequence ${ }^{46}$ (FIG. 4) except for a single base change at position 870 in the $3^{\prime}$ untranslated region. This change might be due to a strain difference (Balb/c for pMCAII, YBR for cosmid 54), a reverse transcriptase error ${ }^{47}$ during the cloning of the $\mathrm{CDNA}$, or the possibility that these sequences represent different genes. An intron-exon junction was found between Gln-220 and Met-221. The restriction map of the exonic region shows no differences when compared with the $3^{\prime}$ untranslated region found in pMCAII (FIG. 5).

Cosmid 103 also contains the $3^{\prime}$ region of a CA II gene. The Eco RI restriction fragment sizes are given in TABLE 2 . The fragments were ordered by partial digestion mapping (data not shown). The restriction pattern of 103 is quite different from cosmids 54 and A5 that also contain $3^{\prime}$ hybridizing regions. FIGURE 5 shows the relative restriction maps of the subclones of hybridizing fragments from

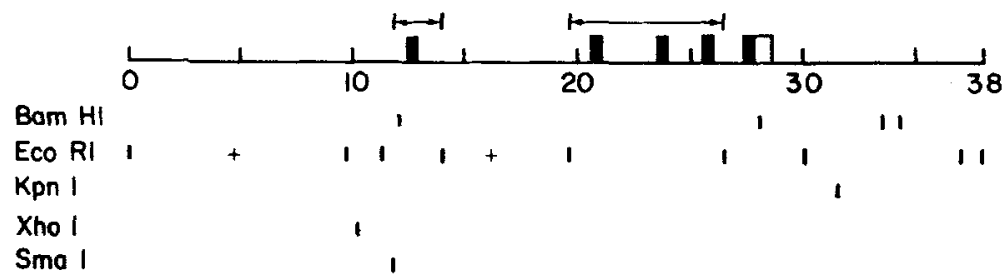

FIGURE 3. Restriction map of the cosmid clone A6. Plus marks indicate additional fragments that have not been mapped. The bars and arrows indicate the approximate location of the exons. The open box is the $3^{\prime}$ untranslated region. The minimum number of exons is shown. 


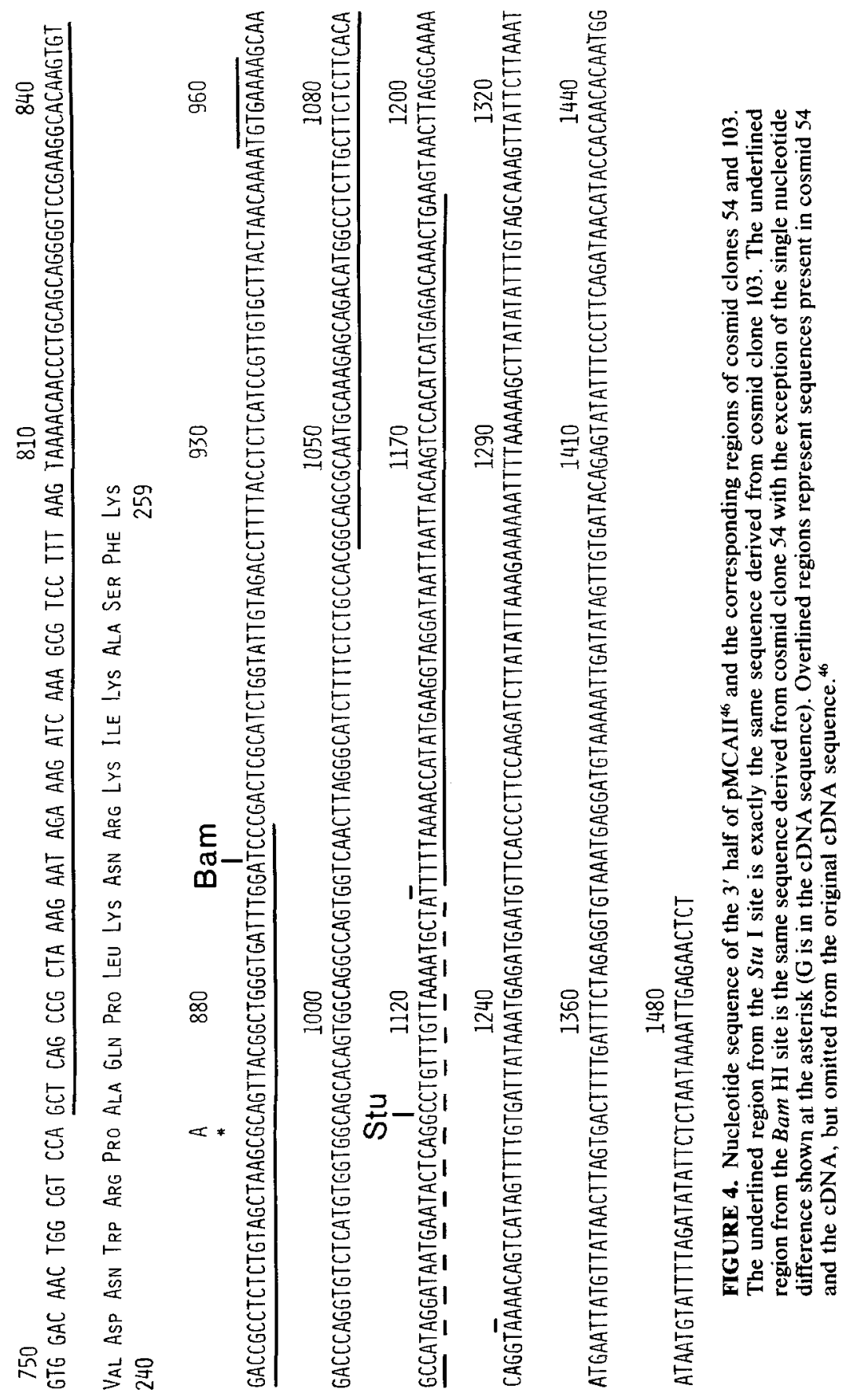




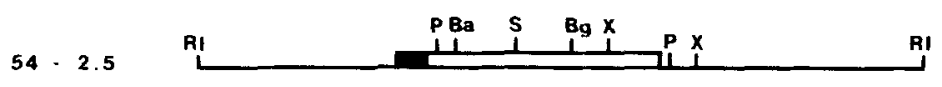

$103 \cdot 2.0$

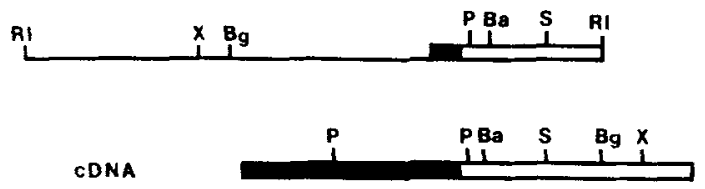

$1 \mathrm{~kb}$

FIGURE 5. Comparison of the restriction maps of two cosmid subclones with the restriction map of the mouse CA II cDNA. The two subclones map at the end of the genomic inserts of the respective cosmid clones. Thus, the Eco RI site at the $5^{\prime}$ end of subclone 54-2.5 and the Eco RI site at the $3^{\prime}$ end of subclone 103-2.0 are artificial sites derived from pJB8. ${ }^{31}$ The thick bars represent structural gene regions (i.e., those that are present in the cDNA) and the black bars represent coding sequence. Note that the restriction sites are the same in these regions between the cosmid subclones and the cDNA. Restriction site designations are as in FIGURE 1.

two of the three cosmids. Sequences surrounding the Stu I site in the subclone from cosmid 103 show that this site is homologous to the site in pMCAII (see FIG. 4).

\section{Mouse CA II Lambda Clones}

Four lambda clones were studied in some depth. The sizes of the fragments produced by digestion with Eco RI are given in TABLE 3. Clone 8.2 contains the 5' end of a CA II gene and clones 8.1,9.1, and 15.1 all contain $3^{\prime}$ ends as determined by hybridization with the $5^{\prime}$ and $3^{\prime}$ specific probes. The restriction map of subclone 8.2-2.7 (derived from clone 8.2 and containing the 2.7-kb Eco RI hybridizing fragment) is given in FIGURE 6. From the cDNA restriction map, it is known that a Tth $111 \mathrm{I}$ site is located at the start codon of the mouse CA II cDNA (see

TABLE 3. Eco RI Fragment Sizes for Mouse Lambda Clones ${ }^{a}$

\begin{tabular}{ccccc}
\hline \multicolumn{5}{c}{ Clone } \\
\hline 8.1 & 8.2 & 9.1 & 15.1 \\
\hline $22.0 \angle$ & $22.0 \angle$ & $22.0 \angle$ & $22.0 \angle$ \\
$10.0^{*} \angle$ & $10.0 \angle$ & $11.0^{*} \angle$ & $10.0^{*} \angle$ \\
7.0 & 4.9 & 7.0 & 7.0 \\
$3.5^{*}$ & $2.7^{*}$ & 4.2 & $3.5^{*}$ \\
& 1.9 & & \\
\hline
\end{tabular}

${ }^{a}$ Fragment sizes are given in kilobase pairs. $\angle$ hybridizes to Charon $30 ;{ }^{*}$ hybridizes to pMCAII. 


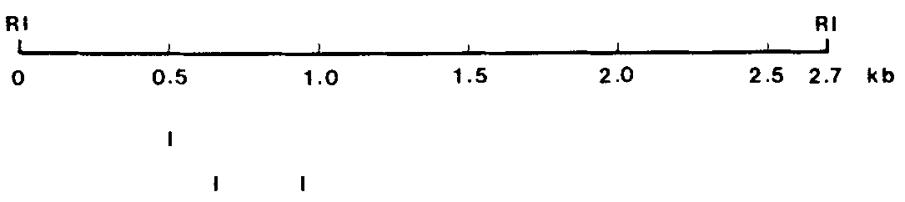

FIGURE 6. Restriction map of mouse lambda subclone 8.2-2.7. This subclone contains the 5 ' region of the mouse $C A$ II gene.

FIG. 1). Sequencing from the Tth 111 I site proximal to the Bam HI site revealed no homology with the sequence of the mouse CA II cDNA near the Tth 111 I site. This strongly suggests that the start codon is located at the Tth 111 I site distal to the Bam HI site.

\section{Human CA II Lambda Clones}

Several human lambda clones containing CA II sequences were isolated and identified by hybridization with pMCAII under low stringency conditions (i.e., $35 \%$ formamide). These were designated $\mathrm{H} 10, \mathrm{H} 11, \mathrm{H} 17, \mathrm{H} 23, \mathrm{H} 24$, and $\mathrm{H} 25$; clones $\mathrm{H} 10, \mathrm{H} 11$, and $\mathrm{H} 25$ were studied in some detail. The Eco RI restriction band sizes are given in TABLE 4 and the hybridizing bands are indicated. The most intense hybridization occurred with the $3.8-\mathrm{kb}$ band in $\mathrm{H} 25$ that was sibcloned for further study. The restriction maps of $\mathrm{H} 25$ and this subclone, $\mathrm{H} 25-3.8$, are shown in FIGURE 7. DNA sequencing from one of the Bam HI sites revealed part of the coding region for a CA II gene as shown in FIGURE 8 along with the homologous region from the mouse gene. The sequence codes for amino acids from approximately 58 to 77 and agrees exactly with the known amino acid sequence. ${ }^{48,49}$ To the 3' side of the first nucleotide of the codon for Val-77 is the beginning of an intervening sequence. The beginning of the next exon was not found within the $\mathbf{5 0}$ nucleotides sequenced downstream from position 77 . There is good agreement between the donor splice site found in $\mathrm{H} 25-3.8$ and the consensus donor splice site sequence. ${ }^{50}$ This subcloned fragment contains no repetitive elements as defined by genomic blot analysis using the subclone as a probe.

TABLE 4. Eco RI Restriction Fragments of Human CA II Clones ${ }^{a}$

\begin{tabular}{lll}
\hline & Clone \\
\hline H10 & H11 & H25 \\
\hline $7.6^{*}$ & $8.7^{*}$ & 5.2 \\
4.3 & 3.0 & $3.8^{* *}$ \\
3.0 & 0.4 & 2.1 \\
& & 1.8 \\
& & 1.7 \\
& & 0.6 \\
\hline
\end{tabular}

${ }^{a}$ Fragment sizes are in kilobase pairs. The single asterisk indicates hybridization to the middle Pst I fragment of pMCAII. The double asterisk indicates hybridization to the S'Pst I fragment of pMCAII. Charon $4 \mathrm{~A}$ arms are not included in the table. 


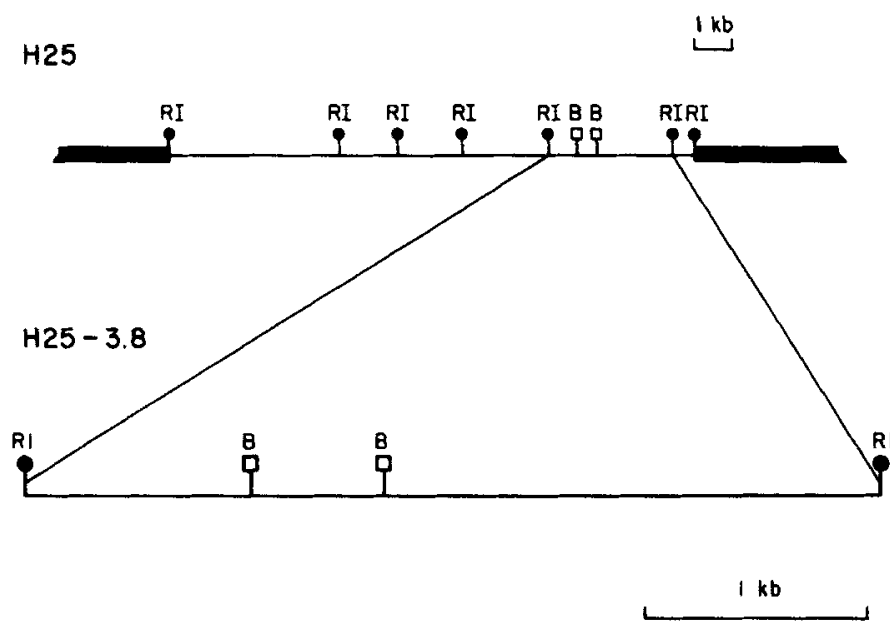

FIGURE 7. Restriction map of human CA II genomic clone $\mathrm{H} 25$ and subclone H25-3.8. The subclone hybridizes with the 5 probe derived from pMCAll.

\section{DISCUSSION}

One of the interesting results of the present study is that there may exist more than one CA II gene as indicated by the nonhomologous $3^{\prime}$ regions of cosmids A5, A6, 54, and 103 . Since there is always a possibility of generating artifacts during the cloning process, it is necessary to remain cautious in the interpretation of these data until a more extensive analysis has been carried out. Several lines of reasoning argue against cloning artifacts. Rearrangements after cloning are one source of artifact. This would seem unlikely in the present case because very few of the restriction fragments are of equivalent size between the three cosmid clones that contain only the 3 ' hybridizing regions. Massive rearrangement of each clone would have had to occur for this to happen. In addition, such rearrangements would in all likelihood also produce deletions. This does not appear to be the case here since all the clones are large and in the size range of normal cosmid clones.

The incorporation of two or more pieces of noncontiguous genomic DNA into a single cosmid clone is another possibility. This seems unlikely since the DNA was size fractionated into pieces of $35-45 \mathrm{~kb}$, the maximum size for a cosmid insert that still allows packaging of the entire recombinant cosmid into a lambda phage particle.

One interesting point is the presence of a $1.8-\mathrm{kb}$ hybridizing $E c o$ RI fragment found in cosmid 103 . This fragment has only been seen in a genomic blot of Eco RI digested mouse DNA hybridized with pMCAII at low stringency (i.e., 35\% formamide). On a blot of clone 103 , the $1.8-\mathrm{kb}$ fragment is weaker than the $2.0-\mathrm{kb}$ fragment (which is of artificial size, because it is one of the two end fragments of the genomic insert).

Duplicated genes that give rise to the same protein product with no (or very few) amino acid differences have been described for other gene systems. One of the best characterized is the case of human $\alpha$-globin where two genes actively 


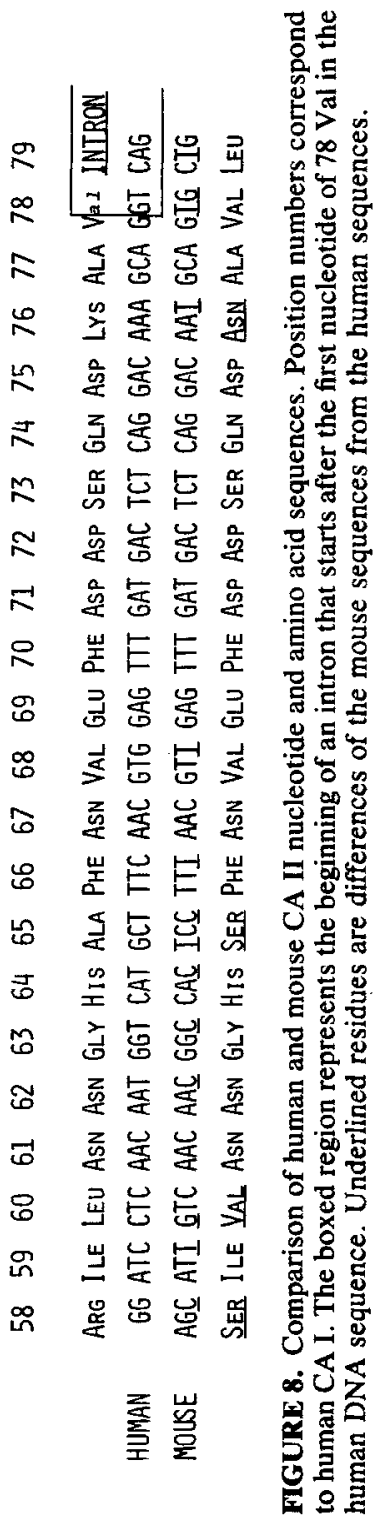


produce products distinguishable at the mRNA level by differences in the $3^{\prime}$ untranslated region but indistinguishable at the protein level. ${ }^{18}$ The goat ${ }^{\mathrm{I}} \alpha$ - and ${ }^{I I} \alpha$-globin genes, while differing by one amino acid in the coding region, have identical $3^{\prime}$ untranslated regions. ${ }^{51}$ Several other examples also exist. ${ }^{52-54}$ Gene conversion events or recent duplications have been postulated to produce these nearly identical gene copies. Assuming that our isolated mouse CA II genes do not represent cloning artifacts, a number of questions immediately arise. Do several CA II genes produce the same product? Or will the genes be found to differ slightly and have differential tissue expression? Clearly, further efforts toward obtaining overlapping clones containing entire genes, finer restriction maps, and additional sequence data are necessary to answer these questions.

The isolation of at least a portion of a human CA II gene provides a probe that will obviously facilitate our ongoing studies on the human CA II gene (or genes). Hybridizing fragments contained in the other human CA II clones have not yet been as extensively characterized as the one in $\mathrm{H} 25$. If multiple CA II or CA IIlike genes do exist in humans, the differences in clinical severity of the CA II deficiencies might therefore be explained by lesions involving one or more of these genes. With the availability of a human CA II probe, such possibilities can now be investigated.

\section{ACKNOWLEDGMENTS}

We thank Dr. Peter J. Curtis for providing the mouse CA II cDNA clone, Dr. Tom Maniatis for the human lambda library, and Richard W. Padgett (U. of North Carolina) for the pJB8 cosmid vector. Heather Hartle in Dr. Miriam H. Meisler's laboratory assisted in screening the YBR mouse cosmid library. Penelope J. Hopkins provided packaging extracts, Susan Old helped to screen the human lambda library, and Ya-Shiou L. Yu assisted in the DNA sequencing.

\section{REFERENCES}

1. MAREN, T. H. 1967. Carbonic anhydrase: Chemistry, physiology, and inhibition. Physiol. Rev. 47: 595-838.

2. LindsKog, S. 1983. Carbonic anhydrase. In Zinc Enzymes. T. G. Spiro, Ed. John Wiley and Sons, Inc. pp. 78-121.

3. CARTER, M. J. 1972. Carbonic anhydrase: Isozymes, properties, distribution, and functional significance. Biol. Rev. 47: 465-513.

4. TASHian, R. E. 1977. Evolution and regulation of the carbonic anhydrase isozymes. In Isozymes: Current Topics in Biological and Medical Research. M. C. Rattazzi, J. G. Scandalios \& G. S. Whitt, Eds. Vol. 2: 21-62. A. R. Liss. New York.

5. PoCker, Y. \& S. L. SARKANEN. 1978. Carbonic anhydrase: Structure, catalytic versatility and inhibition. Adv. Enzymol. 47: 149-274.

6. Lindskog, S., L. E. Henderson, K. K. Kannan, A. Liluas, P. O. Nyman \& B. Strandsberg. 1971. Carbonic anhydrase. In The Enzymes. P. D. Boyer, Ed. Vol. V: 587-665. Academic Press. New York.

7. Tashian, R. E., D. Hewett-Emmett \& M. Goodman. 1983. On the evolution and genetics of carbonic anhydrases I, II, and III. In Isozymes: Current Topics in Biological and Medical Research. M. C. Rattazzi, J. G. Scandalios \& G. S. Whitt, Eds. Vol. 7: 79-100. A. R. Liss. New York.

8. Sapirstein, V. S., P. Strocchi, M. Wesolowski \& J. M. Gilbert. 1983. Characterization and biosynthesis of soluble and membrane-bound carbonic anhydrase in brain. J. Neurochem. 40: 1251-1261. 
9. WhItNey, P. L. \& T. V. BRIGGLe. 1982. Membrane-associated carbonic anhydrase purified from bovine lung. J. Biol. Chem. 257: 12056-12059.

10. Henry, R. P., R. E. Forster, B. T. Storey \& S. J. Dodgson. 1983. Rat lung carbonic anhydrase: A single cytoplasmic isozyme. Fed. Proc. 42: 1269.

11. MCKInLEY, D. N. \& P. L. WhITNEY. 1976. Particulate carbonic anhydrase in homogenates of human kidney. Biochem. Biophys. Acta 445: 780-790.

12. Sanyal, G., N. I. Pessah \& T. H. Maren. 1981. Kinetics and inhibition of membrane-bound carbonic anhydrase from canine renal cortex. Biochem. Biophys. Acta 657: $128-137$.

13. Dodgson, S. J., R. E. Forster II, B. T. Storey \& L. Mela. 1980. Mitochondrial carbonic anhydrase. Proc. Natl. Acad. Sci. USA 77: 5562-5566.

14. Vincent, S. H. \& D. N. Silverman. Carbonic anhydrase activity in mitochondria from rat liver. J. Biol. Chem. 257: 6850-6855.

15. ORKIN, S. H. \& S. C. Goff. 1981. The duplicated human $\alpha$-globin genes: Their relative expression as measured by RNA analysis. Cell 24: 345-351.

16. Barrera-Saldana, H. A., P. H. Seeburg \& G. F. Saunders. 1983. Two structurally different genes produce the same secreted human placental lactogen hormone. J. Biol. Chem. 258: 3787-3793.

17. Rosenfeld, M. G., J.-J. Mermod, S. G. amara, L. W. Swanson, P. E. SawChenko, J. Rivier, W. W. Vale \& R. M. Evans. 1983. Production of a novel neuropeptide encoded by the calcitonin gene via tissue-specific RNA processing. Nature 304: 129-135.

18. Amara, S. G., V. Jonas, M. G. Rosenfeld, E. S. Ong \& R. E. Evans. 1982. Alternative RNA processing in calcitonin gene expression generates mRNAs encoding different polypeptide products. Nature 298: 240-244.

19. Eicher, E. M., R. H. Stern, J. E. Womack, M. T. Davisson, T. H. Roderick \& S. C. REYNOLDS. 1976. Evolution of mammalian carbonic anhydrase loci by tandem duplication; close linkage of $\mathrm{Car}-1$ and $\mathrm{Car}-2$ to the centromere region of chromosome 3 of the mouse. Biochem. Genet. 14: 651-660.

20. Venta, P. J., T. B. Shows, P. J. Curtis \& R. E. Tashian. 1983. Polymorphic gene for human carbonic anhydrase II: A molecular disease marker located on chromosome 8. Proc. Natl. Acad. Sci. USA 80: 4437-4440.

21. DeSimone, J., M. Linde \& R. E. Tashian. 1973. Evidence for linkage of carbonic anhydrase isozyme genes in the pigtailed macaque, Macaca nemestrina. Nature (London) New Biol. 242: 55-56.

22. CarTeR, N. D. 1972. Carbonic anhydrase isozymes in Cavia porcellus, Cavia aperea and their hybrids. Comp. Biochem. Physiol. 43B: 743-747.

23. Kendall, A. G. \& R. E. TAshian. 1977. Erythrocyte carbonic anhydrase I (CA I): Inherited deficiency in humans. Science 197: 471-472.

24. Sly, W. S., D. Hewett-Emmett, M. P. Whyte, Y.-S. Yu \& R. E. Tashian. 1983. Carbonic anhydrase II deficiency as the primary defect in the autosomal recessive syndrome of osteopetrosis with renal tubular acidosis and cerebral calcification. Proc. Natl. Acad. Sci USA 80: 2752-2756.

25. Tashian, R. E., D. Hewett-Emmett, S. J. Dodgson, R. E. Forster, II \& W. S. SLY. 1984. The value of inherited deficiencies of human carbonic anhydrase isozymes in understanding their cellular roles. Ann. N.Y. Acad. Sci. 429: 262-275.

26. MARKS, S. C. \& D. G. WALKER. 1976. Mammalian osteopetrosis-a model for studying cellular and humoral factors in bone resorption. In The Biochemistry and Physiology of Bone. 2nd edition. Bourne, Ed. Vol. 4: 227-301. Academic Press. New York.

27. SPRITZ, R. A. \& B. G. Forget. 1983. The thalassemias: Molecular mechanisms of human genetic disease. Am. J. Hum. Genet. 35: 333-361.

28. CurTis, P. J. 1983. Cloning of mouse carbonic anhydrase mRNA and its induction in mouse erythroleukemic cells. J. Biol. Chem. 258: 4459-4463.

29. Maniatis, T., E. F. Fritch \& J. Sambrook. 1982. Molecular Cloning. Cold Spring Harbor Laboratory. Cold Spring Harbor, NY.

30. Rimm, D. L., D. Hogness, J. KuCERA \& F. R. Blattrer. 1980. Construction of coliphage lambda Charon vectors with Bam HI cloning sites. Gene 12: 301-309. 
31. Ish-Horowicz, D. \& J. T. BuRKE. 1981. Rapid and efficient cosmid vector cloning. Nucleic Acids Res. 9: 2989-2993.

32. Lawn, R. M., E. F. Fritsch, R. C. Parker, G. Blake \& T. Maniatis. 1978. The isolation and characterization of linked $\delta$ - and $\beta$-globin genes from a cloned library of human DNA. Cell 15: 1157-1174.

33. SoutherN, E. M. 1975. Detection of specific sequences among DNA fragments separated by gel electrophoresis. J. Mol. Biol. 98: 503-517.

34. Denhardt, D. T. 1966. A membrane-filter technique for the detection of complementary DNA. Biochem. Biophys. Res. Commun. 23: 641-646.

35. Hanahan, D. \& M. Meselson. 1980. Plasmid screening at high colony density. Gene 10: $63-67$.

36. Benton, W. D. \& R. W. Davis. 1977. Screening ygt recombinant clones by hybridization to single plaques in situ. Science 196: 180-182.

37. Holmes, D. S. \& M. Quigley. 1981. A rapid boiling method for the preparation of bacterial plasmids. Anal. Biochem. 114: 193-197.

38. NoRGARD, M. V. 1981. Rapid and simple removal of contaminating RNA from plasmid DNA without the use of RNase. Anal. Biochem. 113: 34-42.

39. Bolivar, F. 1978. Construction and characterization of new cloning vehicles. III. Derivatives of plasmid pBR322 carrying unique $E c o$ RI sites for selection of $E c o$ RIgenerated recombinant DNA molecules. Gene 4: 121-136.

40. Prentki, P., F. Karch, S. IidA \& J. Meyer. 1981. The plasmid cloning vector pBR325 contains a 482 base-pair-long inverted duplication. Gene 14: 289-299.

41. Hanahan, D. 1983. Studies on transformation of Escherichia coli with plasmids. J. Mol. Biol. 166: 557-580.

42. SMith, H. O. \& M. L. BERnStiel. 1976. A simple method for DNA restriction site mapping. Nucleic Acids Res. 3: 2387-2394.

43. MaXAM, A. M. \& W. Gilbert. 1980. Sequencing end-labeled DNA with base-specific chemical cleavages. In Methods in Enzymology. R. Wu, Ed. Vol. 65: 363-371. Academic Press. New York.

44. LASKEY, R. A. 1980. The use of intensifying screens or organic scintillators for visualizing radioactive molecules resolved by gel electrophoresis. In Methods in Enzymology. Vol. 65: 363-371. Academic Press. New York.

45. JefrReys, A. J. \& R. A. Flavell. 1977. The rabbit $\beta$-globin gene contains a large insert in the coding sequence. Cell 12: 1097-1108.

46. Curtis, P. J., E. Withers, D. Demuth, R. Watt, P. J. Venta \& R. E. Tashian. 1983. The nucleotide sequence and derived amino acid sequence of cDNA coding for mouse carbonic anhydrase II. Gene 25: 325-332.

47. Hewett-Emmett, D., P. J. Venta \& R. E. TAShian. 1982. Features of gene structure, organization, and expression that are providing unique insights into molecular evolution and systematics. In Macromolecular Sequences in Systematics and Evolutionary Biology. M. Goodman, Ed. Plenum Press. New York. pp. 357-405.

48. Henderson, L. E., D. Henriksson \& P. O. Nyman. 1976. Primary structure of human carbonic anhydrase C. J. Biol. Chem. 251: 5457-5463.

49. LiN, K.-T. D. \& H. F. Deutsch. 1974. Human carbonic anhydrases: XII. The complete primary structure of the C isozyme. J. Biol. Chem. 249: 2329-2337.

50. Mount, S. M. 1982. A catalogue of splice junction sequences. Nucleic Acids Res. 10: $459-472$.

51. Schon, E. A., S. M. Wernke \& J. B. Lingrel. 1982. Gene conversion of two functional goat $\alpha$-globin genes preserves only minimal flanking sequences. J. Biol. Chem. 257: 6825-6835.

52. Barsh, G. S., P. H. Seeburg \& R. E. Gelinas. 1983. The human growth hormone gene family: Structure and evolution of the chromosomal locus. Nucleic Acids Res. 11: 3939-3958.

53. Slightom, J. L., A. E. Blechl \& O. Smithies. 1980. Human fetal ${ }^{\mathrm{G}} \gamma$ - and A $\gamma$-globin genes: Complete nucleotide sequences suggest that DNA can be exchanged between these duplicated genes. Cell 21: 627-638.

54. Meisler, M., J. Strahler, K. Wiebauer \& K. K. Thomsen. 1983. Multiple genes 
encode mouse pancreatic amylases. In Isozymes: Current Topics in Biological and Medical Research. M. C. Rattazzi, J. G. Scandalios \& G. S. Whitt, Eds. Vol. 7: 3957. A. R. Liss, Inc. New York.

55. Maniatis, T., R. C. Hardison, E. Lacy, J. Lauer, C. O'Connell, D. Quon, D. K. SiM \& A. Efstratiadis. 1978. The isolation of structural genes from libraries of eukaryotic DNA. Cell 15: 687-701.

56. SEed, B., R. C. PARKer \& N. Davidson. 1982. Representation of DNA sequences in recombinant DNA libraries prepared by restriction enzyme partial digestion. Gene 19: 201-209.

57. ChiA, W., M. R. D. Scott \& P. W. J. RigBY. 1982. The construction of cosmid libraries of eukaryotic DNA using the Homer series of vectors. Nucleic Acids Res. 10: $2503-2520$.

58. ENQUIST, L. \& N. STERNBERg. 1979. In vitro packaging of $\lambda$ Dam vectors and their use in cloning DNA fragments. In Methods in Enzymology. Vol. 68: 281-298. Academic Press. New York.

59. Clarke, L. \& J. Carbon. 1976. A colony bank containing synthetic Col E1 hybrid plasmids representative of the entire $E$. coli genome. Cell 9: 91-96.

60. Grosveld, F. G., H.-H. M. Dahl, E. De Boer \& R. A. Flavell. 1981. Isolation of $\beta$-globin-related genes from a human cosmid library. Gene 13: 227-237.

61. WooD, W. B. 1966. Host specificity of DNA produced by Escherichia coli: Bacterial mutations affected the restriction and modification of DNA. J. Mol. Biol. 16: 118133.

62. Steinmetz, M., A. Winoto, K. Minard \& L. Hood. 1982. Clusters of genes encoding mouse transplantation antigens. Cell 28: 489-498. 